\title{
An Econometric Model for Egyptian Onion Exports
}

\section{Asmaa Mohamed El-Tokhy Bahloul ${ }^{1}$ and Mohamed Osman Abdel Fatah ${ }^{2}$}

${ }^{1}$ Lecture of Agric. Economics, Faculty of Agriculture, Benha University, Egypt.

${ }^{2}$ Associate professor of Agric. Economics, Faculty of Agriculture, Ain Shams University, Egypt.

Received: 07 Oct. 2019 / Accepted 10 Nov. 2019/ Publication date: 25 Nov. 2019

\begin{abstract}
The selection of the Egyptian onion crop due to that the most economic studies indicated that the onion crop is considered one of the most important vegetable crops, which occupies a high position in the Egyptian agricultural export earnings. However, the statistics indicated that the ratio of exports to production fluctuates and decreases.

The results of the current model show that the most critical factors affecting the average of Egyptian per capita consumption of onion according to the simultaneous model is the average of per capita share of domestic production of onion, and the average of price per $\mathrm{kg}$ of Egyptian consumers of onion.

The estimation showed that the most important factors affecting the average of per capita import in the main import markets of Egyptian onion exports (according to the model) are both the average of per capita Egyptian domestic production, China's average export price (a direct relationship), while the average export price of Egyptian onion (inverse relationship). By forecasting total household consumption, it will reach about 2537 thousand tons during 2020, and reach about 2961 thousand tons in 2025 , by increasing about $16.7 \%$ of its value in 2020 using the simultaneous model.

The most important factors affecting the local production of Egyptian onion (according to the model) are the average of per capita UAE imports of the previous year, the average of Egyptian farm price of onion in dollars in the previous year, and the average of per capita consumption of Egyptian onion in the previous year.

The total domestic production is expected to reach about 2783 thousand tons during 2020 and reach about 3620 thousand tons in 2025, representing an increase of $30.1 \%$ of its value in 2020 using the simultaneous model.
\end{abstract}

Keywords: Simultaneous Model, Two- Stage Least Squares, Theil U Test, Prediction and Mechanism of Advancement.

\section{Introduction}

Studying the export, it is necessary to determine the optimal export situation by studying the interrelated economic relations within the system to measure the interaction between these variables. The economic model is defined as the integrated set of mathematical equations that explain the relationship between different economic variables to identify the factors that effect of society or market.

To obtain estimates of the parameters of equations after solving Simultaneous Model, these are called structural equations. The model is also defined as a mathematical representation of relationships that explain the phenomenon. These relationships can be expressed by a set of assumptions about the essential elements of the phenomenon.

These relationships between the elements of the phenomenon are called the model, that consists of a set of relationships, which includes at least one variable, It also appears at least one other relationship in the same model. So economic policies can be shaped by predicting the value of endogenous variables in terms of other variables.

\section{Importance of Research:}

The onion crop is considered as one of the most important vegetable crops. It takes a high position in the Egyptian agricultural exports. 


\section{Problem and Objective of the Study:}

Despite the increase of Egyptian exports of onion crop during the study period (2005-2018), the percentage of exports of onion crop to its production fluctuated and diminished, This has attracted the attention of the research towards identifying the most important variables responsible for the fluctuations in the ratio of exports to production from the onion crop and then in providing hard currency and raising the Egyptian agricultural export earnings, to include them in a proposed mechanism to promote Egyptian exports of this crop.

\section{Data sources and research method:}

The research was based on published and unpublished data from the Central Agency for Public Mobilization and Statistics, FAO, and the internet trade map. The study relied on the method of descriptive and quantitative analysis in the estimation of economic variables using linear and nonlinear models using specialized statistical programs such as, Excel, SPSS V18, Stat graphics, E-views V10 to reach the best forms. Its results are consistent with economic and statistical logic, using a simultaneous econometric model of foreign trade and estimate it with two-stage Least Squares (2SLS) method.

\section{The development of the most important economic variables of Egyptian onion crop:}

\section{Development of the cultivated area of Egyptian onion:}

It is clear from Table (1) that the minimum of cultivated area of Egyptian onion reached 110 thousand feddans in 2006, and the maximum was 184 thousand feddans in 2015, with average about 159 thousand feddans during the study period (2005-2018). Study of the secular trend equation in Table (2) shows that the cultivated area of Egyptian onion increases by a statistically significant about 3.2 thousand feddans per year, which represents $2.02 \%$ of the average period of study. The results shows that $46 \%$ of the changes in onion productivity due to the effect is the time factor.

\section{Development of Egyptian Onion Productivity:}

It is clear from Table (1) that the minimum of Egyptian onion productivity reached 12.2 tons/ feddan in 2006, and the maximum 15.4 tons/feddan in 2017, with average about 13.8 tons/feddan during the study period (2005-2018). The study of the secular trend equation in Table (2) shows that the productivity of Egyptian onion increased by a statistically significant about 0.23 tons / feddan per year, which represents $1.7 \%$ of the average period of study. The results shows that $92 \%$ of the changes in onion productivity due to the effect is the time factor.

Table 1: Development of the most important economic variables of the onion crop during the period (2005-2018).

\begin{tabular}{|c|c|c|c|c|c|c|}
\hline Years & $\begin{array}{c}\text { Cultivated } \\
\text { area } \\
\text { (thousand } \\
\text { fed.) }\end{array}$ & $\begin{array}{l}\text { Productivity } \\
\text { (Ton /fed.) }\end{array}$ & $\begin{array}{c}\text { Farm } \\
\text { Price } \\
\text { (dollar / } \\
\text { fed.) }\end{array}$ & $\begin{array}{c}\text { Total } \\
\text { consumption } \\
\text { (Thousand } \\
\text { tons) }\end{array}$ & $\begin{array}{c}\text { Total } \\
\text { exports } \\
\text { (Thousand } \\
\text { Tons) } \\
\end{array}$ & $\begin{array}{c}\text { Total } \\
\text { production } \\
\text { (Thousand } \\
\text { Tons) }\end{array}$ \\
\hline 2005 & 156 & 12.3 & 134 & 1635 & 254 & 1925 \\
\hline 2006 & 110 & 12.2 & 284 & 1406 & 161 & 1347 \\
\hline 2007 & 140 & 12.6 & 342 & 1373 & 89 & 1756 \\
\hline 2008 & 148 & 13.2 & 289 & 1700 & 162 & 1949 \\
\hline 2009 & 158 & 13.5 & 289 & 2201 & 193 & 2129 \\
\hline 2010 & 166 & 13.9 & 374 & 1894 & 353 & 2304 \\
\hline 2011 & 167 & 13.8 & 716 & 2000 & 357 & 2304 \\
\hline 2012 & 160 & 13.8 & 786 & 2097 & 229 & 2199 \\
\hline 2013 & 146 & 14.5 & 624 & 1485 & 258 & 2115 \\
\hline 2014 & 183 & 14.7 & 771 & 2350 & 349 & 2680 \\
\hline 2015 & 184 & 14.6 & 332 & 2544 & 445 & 2692 \\
\hline 2016 & 155 & 14.3 & 372 & 2019 & 378 & 2219 \\
\hline 2017 & 181 & 15.4 & 376 & 2410 & 365 & 2772 \\
\hline 2018 & 175 & 15.1 & 391 & 2432 & 210 & 2641 \\
\hline Mean & 159 & 13.8 & 434 & 1968 & 272 & 2217 \\
\hline
\end{tabular}

Sources:

- Economic Affairs Bulletins, Ministry of Agriculture and Land Reclamation.

- Internet (Trade map). 


\section{The development of the farm price of Egyptian onion:}

It is clear from Table (1) that the minimum farm price of Egyptian onion reached about 134 dollar / ton in 2003, and the maximum was about 786 dollar/ ton in 2012, with an average about 434 dollar/ ton during the study period (2005-2018). The equation of the secular trend in Table (2) shows that the quadratic form is the best mathematical form where the farm price started to increase by a statistically significant, then started decreasing about 17.4 dollar / feddan per year. The results show that $56 \%$ of the changes in the farm price of onion are due to the effect reflected by the variables of the time factor.

\section{The development of consumption of Egyptian onion:}

It is clear from Table (1) that the minimum amount of consumption of Egyptian onion reached about 1373 thousand tons in 2007, and the maximum was about 2544 thousand tons in 2015 with an average about 1968 thousand tons during the study period (2005-2018). The secular trend equation in Table (2) showed that the consumption of Egyptian onion increased by a statistically significant about 71.96 thousand tons per year, representing $3.7 \%$ of the average period of study, and the results showed that $57 \%$ of the changes in the consumption of onion due to the effect of time factor.

\section{The development of the Egyptian onion exports:}

The average quantity of Egyptian exports of onion to the essential importing countries was about 272 thousand tons during the study period that the minimum reached about 89 thousand tons in 2007 , and the maximum was about 445 thousand tons in 2015 with an average about 272 thousand tons during the study period (2005-2018). The secular trend equation in Table (2) showed that the exports of Egyptian onion increased by a statistically significant It was about 14.6 thousand tons per year, which represents $5.4 \%$ of the average period of study, and it showed that $34 \%$ of the changes in the number of Egyptian exports of onion due to the effect of time factor.

\section{The development of the quantity of production of Egyptian onion:}

The average amount of Egyptian onion production reached about 2217 thousand tons during the study period, it is clear from Table (1) that the amount of onion production increased by a statistically significant amounted to about 80.1 thousand tons per year, representing $3.6 \%$ of the average, the results showed that $70 \%$ of the changes in production of onion due to the effect of time factor.

Table 2: Equations of the secular trend of the most important economic variables onion crop during the period (2005-2018)

\begin{tabular}{llccc}
\hline Statement & \multicolumn{1}{c}{ The equation } & $\mathbf{R}^{2}$ & F & $\begin{array}{c}\text { \% Of annual } \\
\text { change }\end{array}$ \\
\hline Cultivated area & $\begin{array}{l}\hat{\mathrm{Y}}_{\mathrm{i}}=135+3.2 \mathrm{X}_{\mathrm{i}} \\
(15.8)^{* *}(3.2)^{* *}\end{array}$ & 0.49 & 10.2 & 2.02 \\
Productivity & $\begin{array}{l}\hat{\mathrm{Y}}_{\mathrm{i}}=1231+023 \mathrm{X}_{\mathrm{i}} \\
(76)^{* *}(12.1)^{* *}\end{array}$ & 0.92 & 145.9 & 1.7 \\
Farm Price & $\begin{array}{l}\hat{\mathrm{Y}}_{\mathrm{i}}=-48+148.5 \mathrm{X}_{\mathrm{i}}-8.7 \mathrm{X}_{\mathrm{i}}^{2} \\
(-0.3)(3.5)^{* *}(-3.1)^{* *}\end{array}$ & 0.56 & 6.6 & -- \\
$\begin{array}{l}\text { Domestic } \\
\text { consumption }\end{array}$ & $\begin{array}{l}\hat{\mathrm{Y}}_{\mathrm{i}}=1427.9+71.96 \mathrm{X}_{\mathrm{i}} \\
(9.4)^{* *}(4.01)^{* *}\end{array}$ & 0.57 & 16.1 & 3.7 \\
Quantity of exports & $\begin{array}{l}\hat{\mathrm{Y}}_{\mathrm{i}}=162.5+14.6 \mathrm{X}_{\mathrm{i}} \\
(3.3)^{* *}(2.5)^{*}\end{array}$ & 0.34 & 6.3 & 5.4 \\
Domestic production & $\begin{array}{l}\hat{\mathrm{Y}}_{\mathrm{i}}=1615.9+80.1 \mathrm{X}_{\mathrm{i}} \\
(12.5)^{* *}(5.3)^{* *}\end{array}$ & 0.70 & 27.8 & 3.6 \\
\hline
\end{tabular}

\section{Where:}

$\hat{Y}$ i: the estimated value of the dependent variable.

Xi: time factor for the period (2005-2018) where $\mathrm{i}=(1,2,3, \ldots, 14)$.

(T) value, $\left(\mathrm{R}^{2}\right)$ the coefficient of determination, and $(\mathrm{F})$ the total significance of the model.

$(*)$ Indicates the significance of regression coefficients at a significant level $(0.05)$.

$(* *)$ Indicates the significance of regression coefficients at the level of significance $(0.01)$. 
Source: Results of the statistical analysis of the data table (1).

\section{The simultaneous econometric model of the Egyptian onion:}

\section{A- Econometric Model Description:}

The model consists of three basic functions: demand function, supply function and market equilibrium function.

\section{1) Demand Side:}

The demand side consists of two relationships: the domestic consumption equation and the exports equation.

The following variables illustrate the Egyptian consumption equation:

A-

$$
\mathrm{Y} 1 \mathrm{i}=\mathrm{F}(\mathrm{X} 1 \mathrm{i}, \mathrm{X} 2 \mathrm{i}, \mathrm{X} 3 \mathrm{i}, \mathrm{X} 4 \mathrm{i}, \mathrm{X} 5 \mathrm{i}, \mathrm{Y} 2 \mathrm{i}, \mathrm{Y} 3 \mathrm{i})
$$

\section{Where:}

Y1i: Average per capita of Egyptian consumption (kg).

X1i: Egyptian imports per capita $(\mathrm{kg})$.

X2i: per capita of Egyptian per capita Gross National Income (dollars).

X3i: Consumer price of the Egyptian onion (dollars $/ \mathrm{kg}$ ).

$\mathrm{X} 4 \mathrm{i}$ : Imports price of the Egyptian consumer (dollars/kg).

X5i: Average per capita of foreign consumption in major importing countries without Egyptian exports.

Y2i: Average foreign per capita of Egyptian exports in the most important markets (kg).

Y3i: Average per capita of Egyptian production $(\mathrm{kg})$.

\section{B - Equation of Egyptian exports, illustrate by the following variables:}

Y2i = F (X6i, X7i, X8i, X9i, X10i, X11i, X12i, X13i, X14i, X15i, X16i, X5i, Y1i, Y3i)

\section{Where:}

Y2i: Average foreign per capita of Egyptian exports in the main imported markets $(\mathrm{kg})$.

X6i: The average of Egyptian export price (dollar/ kg).

X7i: The average of China export price (dollar/ $\mathrm{kg}$ ) (one of the most competitive markets).

X8i: The average of India export price (dollar/ kg) (one of the most competitive markets).

X9i: The average of Spain export price (dollar/ kg) (one of the most competitive markets).

X10i: The average of Poland export price (dollar/ kg) (one of the most competitive markets).

X11i: The average of Germany export price (dollar/ kg) (one of the most competitive markets).

$\mathrm{X} 12 \mathrm{i}$ : The average exchange rate of the dollar to pound.

X13i: Average per capita of Saudi national income (dollar per year for person).

X14i: Average per capita of Dutch national income (dollar per year for person).

X15i: Average per capita of Russian national income (dollar per year for person)..

X16i: Average foreigner per capita of national income (dollar per year for person)..

X5i: Average foreigner per capita of consumption in the main importing countries without Egyptian exports.

Y1i: Average per capita of Egyptian consumption ( $\mathrm{kg} / \mathrm{year})$.

Y3i: Average per capita of Egyptian production ( $\mathrm{kg} /$ year).

\section{2) Supply-side:}

The following variables illustrate the Egyptian production equation:

Y3T = F (X6-t, X17-t, X18-t, X19-t, X20-t, X21-t, X5i, Y1-t, Y2-t) 


\section{Where :}

Y3i: Average per capita of Egyptian production $(\mathrm{kg})$ for i year.

X6i-t: The average of Egyptian export price (dollar/ kg).

X17i-t: Average per capita of Saudi Arabia production $(\mathrm{kg})$ for the previous year.

X18i-t: Average per capita of Dutch production $(\mathrm{kg})$ for the previous year.

X19i-t: Average per capita of Russian production $(\mathrm{kg})$ for the previous year.

X20i-t: Average foreigner per capita of England production ( $\mathrm{kg}$ ) for the previous year.

X21i-t: The average of Egyptian farm price (dollars) for the previous year.

X5i: Average per capita of the most important import markets without Egyptian exports ( $\mathrm{kg})$.

Y1i-t: Average per capita of Egyptian consumption $(\mathrm{kg})$ for the previous year.

Y2i-t: Average foreigner per capita of from Egyptian exports $(\mathrm{kg})$ for the previous year.

\section{3) Market equilibrium function:}

It is an equation that shows the balance of supply and demand. It includes the equation of onion consumption, exports and production.

$$
Y 4 i=Y 1 i+Y 2 i+Y 3 i
$$

\section{The model variables are divided into endogenous and exogenous variables:}

1- The equilibrium value from within the model and illustrated by the variables values Y1i, Y2i, Y3i.

2 - Exogenous variables: These are variables values that determined from outside the model, maybe predetermined, or lagged variables.

\section{B- Results of statistical estimation of Egyptian onion crop and interpretation of results:}

The model results showed that the two-stage least squares method (2SLS) was the most appropriate method to use during the period (2005-2018) as follows:

\section{1- Equation of Egyptian onion consumption:}

$$
\begin{aligned}
& \operatorname{Ln} \hat{Y} 1 \mathrm{i}=0.13-0.03 \operatorname{Ln} x 3 \mathrm{i}+0.91 \text { Ln y } 3 \mathrm{i} \\
& \quad(1.18)(-2.1) *(4.4) * * \\
& \mathrm{R}^{2}=0.64 \quad \text { adj. } \mathrm{R}^{2}=0.53 \quad \text { D. } \mathrm{W}=2.8
\end{aligned}
$$

\section{2- Equation of Egyptian onion exports:}

$$
\begin{array}{ccc}
\operatorname{Ln} \hat{\mathrm{Y}}_{2 \mathrm{i}}=-4.8 & \operatorname{Ln}-0.27 \operatorname{Ln} \mathrm{x}_{6 \mathrm{i}}+0.74 \operatorname{Ln} \mathrm{x}_{7 \mathrm{i}}+1.62 \operatorname{Ln} \mathrm{y}_{3 \mathrm{i}} \\
(-2.2)^{*} & (-1.9)^{*} \quad(3.1)^{* *} \quad(2.6)^{* *} \\
\mathrm{R}^{2}=0.63 & \text { adj. } \mathrm{R}^{2}=0.52 \quad \mathrm{D} . \mathrm{W}=1.7
\end{array}
$$

\section{3- Equation of Egyptian onion production:}

$$
\begin{aligned}
& \operatorname{Ln} \hat{Y}_{3 \mathrm{i}}=1.51+0.06 \operatorname{Ln} \mathrm{x}_{6 \mathrm{i}-\mathrm{t}}-0.34 \operatorname{Ln} \mathrm{x}_{20 \mathrm{i}-\mathrm{t}}+0.08 \operatorname{Ln} \mathrm{x}_{21 \mathrm{i}-\mathrm{t}}+0.41 \operatorname{Ln} \mathrm{y}_{1 \mathrm{i}-\mathrm{t}} \\
& (8.9)^{* *} \quad(2.3)^{*} \quad(-2.5)^{*} \quad(1.5) \quad(3.1)^{* *} \\
& \mathrm{R}^{2}=0.73 \quad \text { adj. } \mathrm{R}^{2}=0.62 \quad \text { D. } \mathrm{W}=2.7-
\end{aligned}
$$

It is clear from the first equation that, the average price of the Egyptian consumer from onion $\left(\mathrm{X}_{1 \mathrm{i}}\right)$ increases by $10 \%$ led to decrease the average per capita of Egyptian onion consumption $\left(\mathrm{Y}_{1 \mathrm{i}}\right)$ by $0.3 \%$, while increasing the average per capita of Egyptian production $\left(\mathrm{Y}_{3 \mathrm{i}}\right)$ by $10 \%$. The average of Egyptian consumption per capita increased by $9.1 \%$. The most of regression parameters were significant and that the changes in the average per capita of Egyptian onion consumption by $53 \%$ due to changes in the mentioned variables.

Thus, the most affecting factors on the average per capita of Egyptian onion consumption are the average per capita of domestic production of onion (positive relationship), and the average price of Egyptian consumer of onion per $\mathrm{kg}$ (inverse relationship). 
The second equation shows that the average foreign per capita of Egyptian exports in the most important markets for the import of Egyptian onion $\left(\mathrm{Y}_{2 \mathrm{i}}\right)$ decreases by $2.9 \%$, by increasing the average of Egyptian export price of onion $\left(\mathrm{X}_{6 \mathrm{i}}\right)$ by $10 \%$. While, the average of export price of China $\left(\mathrm{X}_{7 \mathrm{i}}\right)$ increased by $10 \%$. The average of foreign exports of Egyptian exports per capita in the most import markets of Egyptian onion increased by $7.4 \%$. The average of Egyptian onion production per capita $\left(\mathrm{Y}_{3 \mathrm{i}}\right)$ increased by $10 \%$ led to increase the average of foreign exports of Egyptian exports per capita in the import markets from Egyptian onion by $16.2 \%$ the most of parameters in the model are significant. The results showed that $52 \%$ of the changes in the average of foreign exports of Egypt per capita due to changes in the previous variables.

Therefore, the most factors affecting on the average of foreign per capita in import markets from Egyptian onion exports (according to the model) are the average per capita of Egyptian domestic production and the average of China export price (positive relationship). While, the average of Egyptian onion export price ( Inverse relationship).

The third equation shows that the increase of both average of Egyptian onion export price in the previous year $\left(\mathrm{X}_{6 \mathrm{i}-\mathrm{t}}\right)$, average of Egyptian onion farm price (dollars $\left./ \mathrm{kg}\right)$ in the previous year $\left(\mathrm{X}_{21 \mathrm{i}-\mathrm{t}}\right)$, and the average per capita of Egyptian onion consumption in the previous year $\left(\mathrm{Y}_{1 \mathrm{i}-\mathrm{t}}\right)$ by $10 \%$ led to increase the average per capita of production $\left(\mathrm{Y}_{3 \mathrm{i}}\right)$ by $0.6 \%, 0.8 \%$ and $4.1 \%$. respectively during the study period (2005-2018). The increase in the average per capita of local production of British onion in the previous year $\left(\mathrm{X}_{20 \mathrm{i}-\mathrm{t}}\right)$ by $10 \%$ led to a decrease in the average per capita of Egyptian production in the current year $\left(\mathrm{Y}_{3 \mathrm{i}}\right)$ by $3.4 \%$. All the parameters of the model were significant. Also the results shows that about $62 \%$ of the changes in the average per capita of Egyptian production onion due to changes in the mentioned variables.

So, the important factors affecting the local production of Egyptian onion (according to the model) are the average per capita of UAE imports for the previous year, the average farm price of Egyptian onion (dollars) in the previous year, and the average per capita of Egyptian onion consumption during the previous year.

\section{The prediction of endogenous variables behavior of the Egyptian onion crop model:}

Scientific prediction of economic phenomena behavior is considered as an important objective of econometrics. It is a quantitative estimate of the expected value of dependent variables in the future based on available previous and current information. Which depended on the behavior of the phenomena in the past, Scientific prediction assumes that the behavior of economic phenomena in the near future is only an extension of the behavior of these phenomena in the recent past, but suddenly changes unexpectedly led to the inaccuracy of scientific predictions of economic phenomena in the future.

\section{The estimated regression model can be performed by using the Theil (U) test.}

The performance of the estimated regression model can be judged by using the Theil (U) unequal coefficient test. The Theil (U) unequal coefficient is defined as:

$$
\begin{aligned}
\mathbf{U} & =\frac{\sqrt{\left.\frac{1}{N}-\sum_{t=1}^{N} \hat{Y}_{t}-Y_{t}\right)^{2}}}{\sqrt{\frac{1}{N} \sum_{t=1}^{N}\left(\hat{Y}_{t}\right)^{2}}+\sqrt{\frac{1}{N} \sum_{t=1}^{N}\left(Y_{t}\right)^{2}}} \\
t & =1,2, \ldots, N
\end{aligned}
$$

Where:

$\mathrm{N}$ : observations number, Yi: the actual value of the dependent variable, Y $i$ : the estimated value of the dependent variable.

The $U$ value ranges from zero to one. If $U$ is close to zero $(U=0)$ the estimated regression model's ability to predict the estimation period will be good. If $U$ moves away from zero and approaches one $(U>0)$ the estimated regression model's ability to predict the estimation period will be bad. 
Table 3: Results of Theil $U$ test for the variables of the simultaneous model, the general trend and the best stat graphics model.

\begin{tabular}{llccc}
\hline $\mathbf{M}$ & Internal variables of the market equilibrium model & $\begin{array}{c}\text { Trend } \\
\mathbf{U}\end{array}$ & $\begin{array}{c}\text { Simultaneous model } \\
\text { U }\end{array}$ & $\begin{array}{c}\text { U } \\
\text { ARIMA }\end{array}$ \\
\hline $\mathbf{1}$ & Total Domestic Consumption of Egyptian OnionY & $\mathbf{0 . 0 0 0 0 6}$ & $\mathbf{0 . 0 0 0 0 4}$ & $\mathbf{0 . 0 0 0 0 5}$ \\
\hline $\mathbf{2}$ & $\begin{array}{l}\text { Total Egyptian Onion Exports to the most importing } \\
\text { Countries } \mathrm{Y}_{2 \mathrm{i}}\end{array}$ & $\mathbf{0 . 0 0 1}$ & $\mathbf{0 . 0 0 0 7}$ & $\mathbf{0 . 0 0 1}$ \\
\hline $\mathbf{3}$ & Gross Domestic Production of Egyptian Onion Y3i & $\mathbf{0 . 0 0 0 0 4}$ & $\mathbf{0 . 0 0 0 0 1}$ & $\mathbf{0 . 0 0 0 0 5}$ \\
\hline $\begin{array}{l}\text { Source: } \text { The results of the Thiel U test analyses from data at tables }(1,2), \text { the results of the Simultaneous model and Stat } \\
\text { graphics. }\end{array}$ & & &
\end{tabular}

Table (4) shows the expected values of the total Egyptian domestic consumption, production, and the total Egyptian onion exports to the most import markets, for the period (20202025), using the single-equation model, simultaneous equations model, random walk model and ARIMA model. The prediction results show that the total domestic consumption will reach about 2579 thousand tons during 2020 and reach about 2939 thousand tons in 2025, an increase of approximately $13.9 \%$ of its value in 2020 using the single equation model. The same table shows that the total domestic consumption will reach about 2537 thousand tons during 2020 and reach about 2961 thousand tons in 2025, an increase of approximately $16.7 \%$ of its value in 2020 using the simultaneous model. It is evident from the results of the prediction using ARIMA model $(0.1,1)$ that the total domestic consumption will reach about 2550 thousand tons during 2020 and reach about 2912 thousand tons in 2025, an increase of approximately $14.2 \%$ of its value in 2020.

Table 4: The prediction of the total domestic consumption, exports of the most importing markets and production of Egyptian Onion using single equation model, simultaneous model, random walk model and Box-Genkis (ARIMA) methodology during the period (2020-2025).

\begin{tabular}{|c|c|c|c|}
\hline \multicolumn{4}{|c|}{$\begin{array}{ll}\text { Total Egyptian consumption (thousand tons) } \\
\end{array}$} \\
\hline Years & Single Equation & Simultaneous model & $\begin{array}{l}\text { Model Box Genkis } \\
\text { *Methodology }\end{array}$ \\
\hline 2020 & 2579 & 2537 & 2550 \\
\hline 2021 & 2651 & 2619 & 2622 \\
\hline 2022 & 2723 & 2702 & 2695 \\
\hline 2023 & 2795 & 2786 & 2767 \\
\hline 2024 & 2867 & 2873 & 2840 \\
\hline 2025 & 2939 & 2961 & 2912 \\
\hline \multicolumn{4}{|c|}{ Total Egyptian exports (thousand tons) } \\
\hline Years & $\begin{array}{c}\text { Single - equation } \\
\text { models Total exports }\end{array}$ & $\begin{array}{l}\text { Simultaneous model } \\
\text { The most import markets }\end{array}$ & ** Random Walk Model \\
\hline 2020 & 395 & 482 & 203 \\
\hline 2021 & 410 & 519 & 200 \\
\hline 2022 & 424 & 559 & 196 \\
\hline 2023 & 439 & 602 & 193 \\
\hline 2024 & 454 & 648 & 190 \\
\hline 2025 & 468 & 697 & 186 \\
\hline \multicolumn{4}{|c|}{ Gross domestic production (thousand tons) } \\
\hline Years & $\begin{array}{l}\text { Single - equation } \\
\text { models }\end{array}$ & Simultaneous model & $\begin{array}{c}\text { Box Genkis Methodology } \\
*_{* *}\end{array}$ \\
\hline 2020 & 2897 & 2783 & 2860 \\
\hline 2021 & 2977 & 2935 & 2931 \\
\hline 2022 & 3057 & 3094 & 3002 \\
\hline 2023 & 3138 & 3261 & 3073 \\
\hline 2024 & 3218 & 3436 & 3144 \\
\hline 2025 & 3298 & 3620 & 3215 \\
\hline
\end{tabular}

* Form $(0,1,1)$ with constant ARIMA. ** Random Walk Model *** Model $(0,2,2)$ with constant ARIMA.

Source: Results of the single, ARIMA model and random walk equations. 
The same table shows that the total Egyptian exports to the most important import markets will reach about 395 thousand tons during 2020 and reach about 468 thousand tons in 2020, an increase of approximately $18.5 \%$ of its value in 2020 using a single equation model. As it seems from the same table, total Egyptian exports will reach about 482 thousand tons during 2020 and reach about 687 thousand tons in 2025, an increase representing approximately $42.5 \%$ of its value in 2020 using the simultaneous model. The total Egyptian exports will decline to reach about 203 thousand tons during 2020 and reach about 168 thousand tons in 2020, a decrease approximately $17.5 \%$ of its value in 2020 by using the random walk model

Also, table (4) has shown that the total domestic production will reach about 2897 thousand tons during 2020 and reach about 3298 thousand tons in 2025, an increase of approximately $13.8 \%$ of its value in 2020 using the single equation model. As shown by the same table, the total domestic production will reach about 2783 thousand tons during 2020 and reach about 3620 thousand tons in 2025 , an increase of approximately $30.1 \%$ of its value in 2020 using the simultaneous model. As shown in the same table, the total domestic production will reach about 2860 thousand tons during 2020 and reach about 3215 thousand tons in 2025, an increase of approximately $12.4 \%$ of its value in 2020 using the ARIMA model $(0,2,2)$.
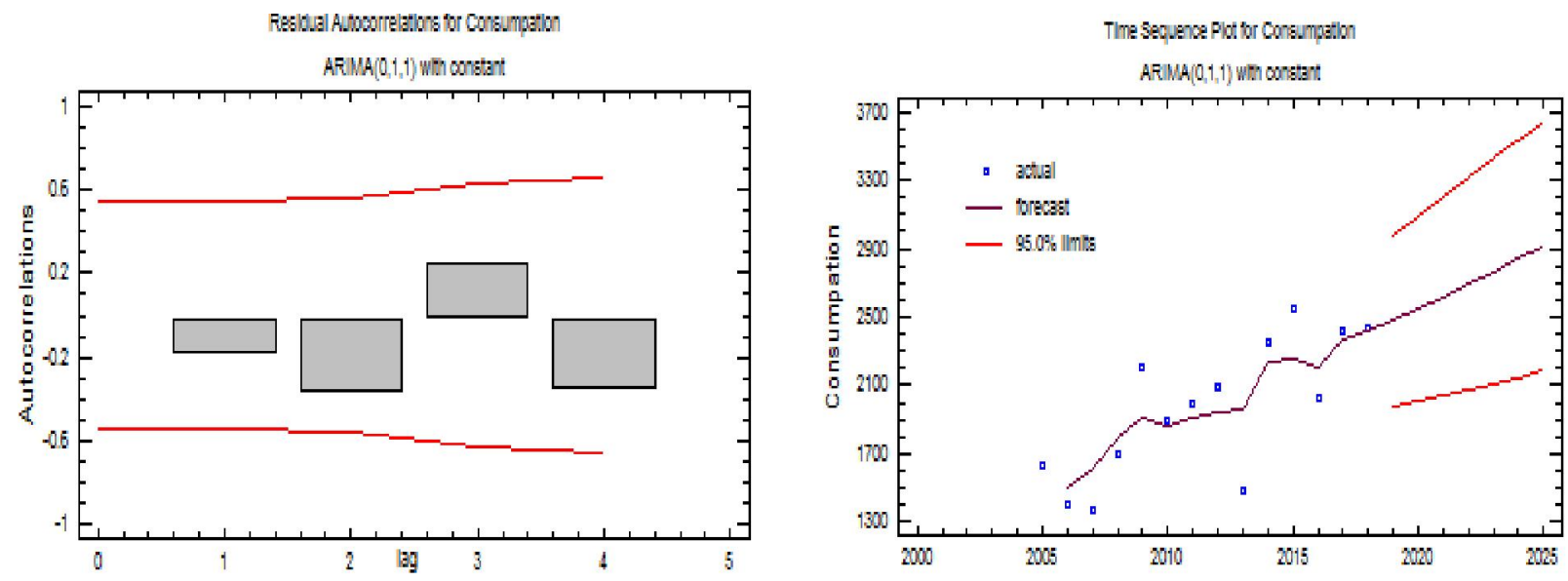

Fig. 1: ARIMA model $(0.1,1)$ to predict the total Egyptian domestic consumption of onion during the period (2020-2025).

Source: Analysis results by using STATGRAPHICS Centurion.
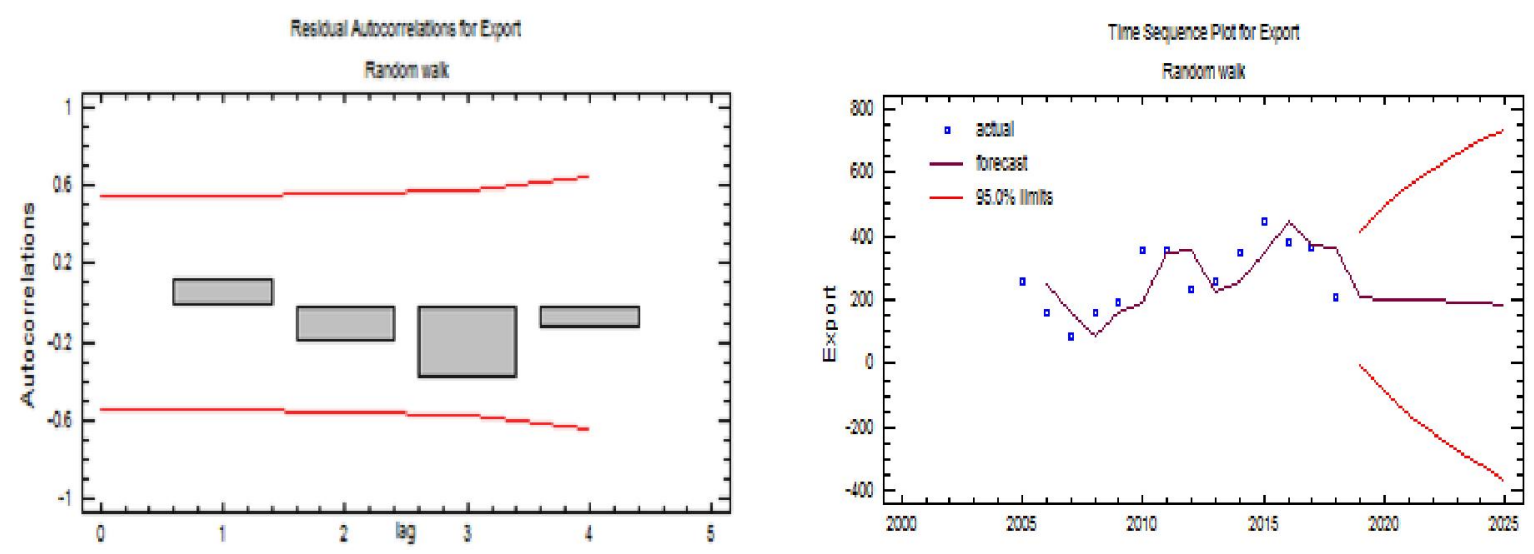

Fig. 2: The random walk model to predict the total Egyptian exports in the most important import markets of Egyptian onion during the period (2020-2025).

Source: Analysis results by using STATGRAPHICS Centurion. 
Fesbugl Aunoorrelations for Prowastion

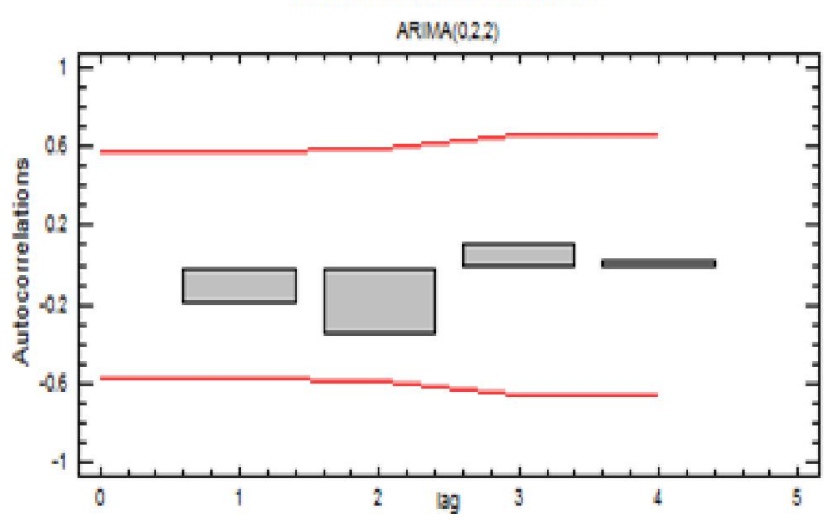

The Sequence Plot tor Producation

ARIMA(022)

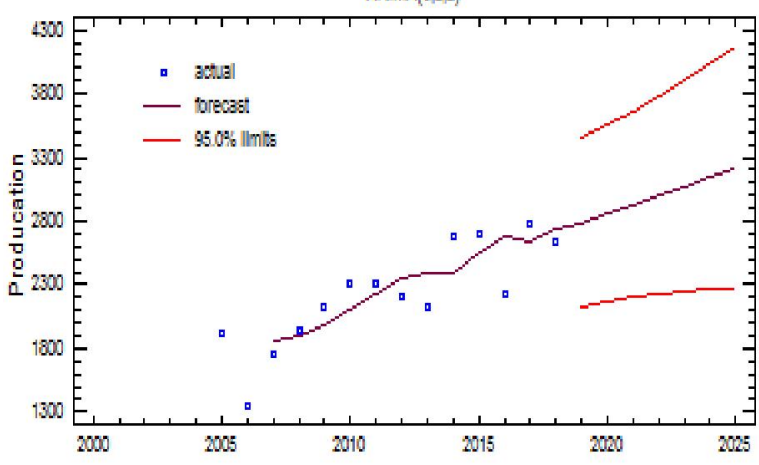

Fig. 3: ARIMA model $(0.2,2)$ to predict the Egyptian GDP of onion during the period $(2020-2025)$. Source: Analysis results by using STATGRAPHICS Centurion.

Comparison of the three models graphically:

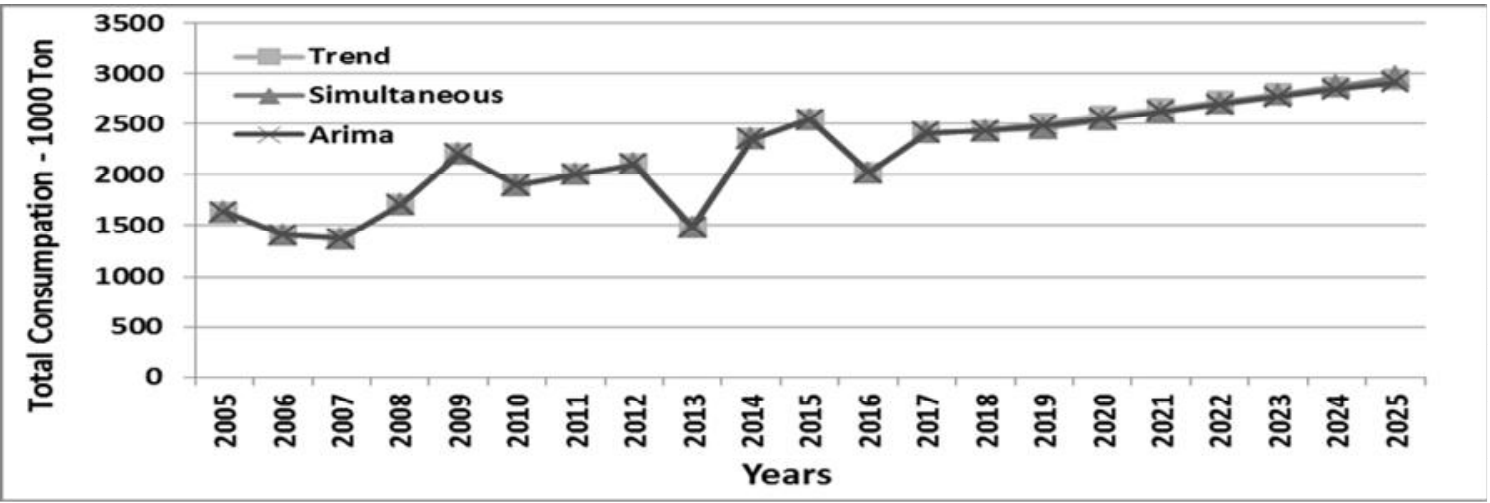

Fig. 4: A comparison between the prediction models of total Egyptian onion domestic consumption during the period (2020-2025).

Source: Tables (1 and 4) in the study

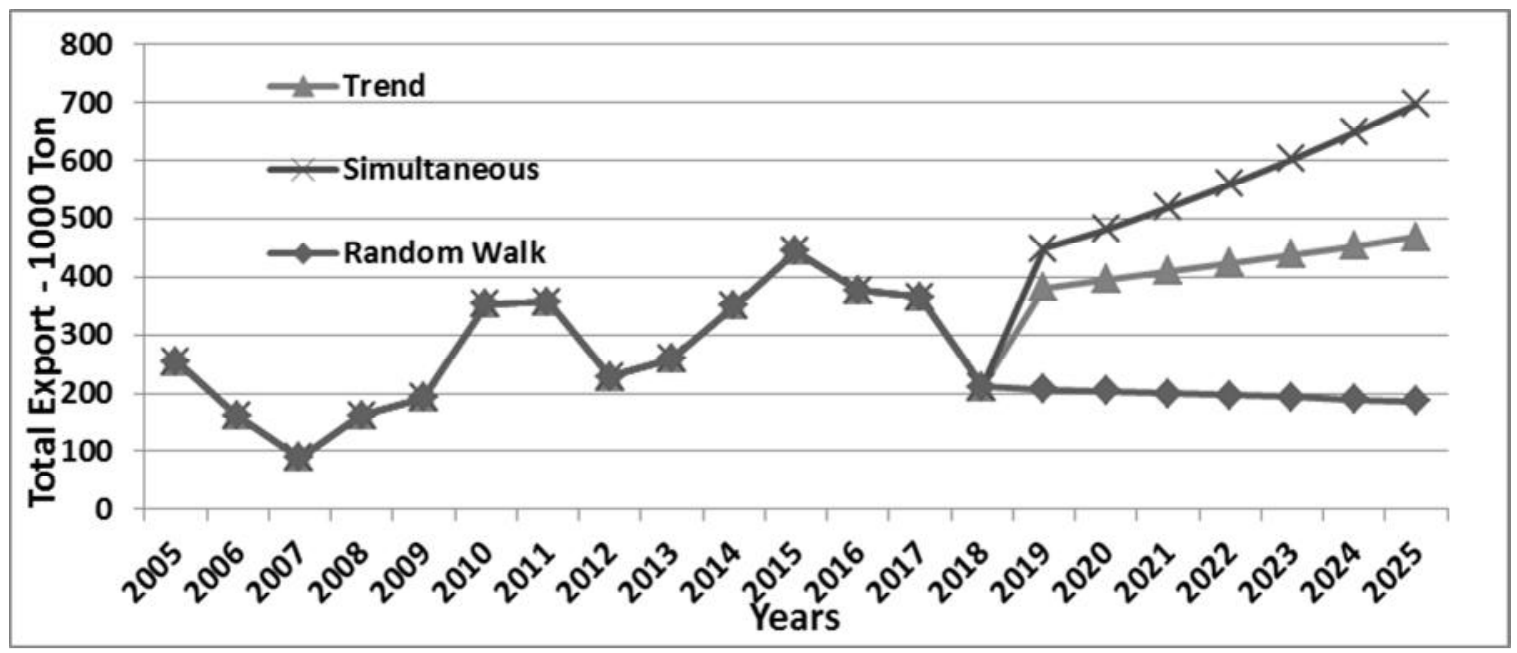

Fig. 5: Comparison between the prediction models of total Egyptian exports in the most import markets of Egyptian onion during the period (2020-2025).

Source: Tables (1 and 4) in the study. 


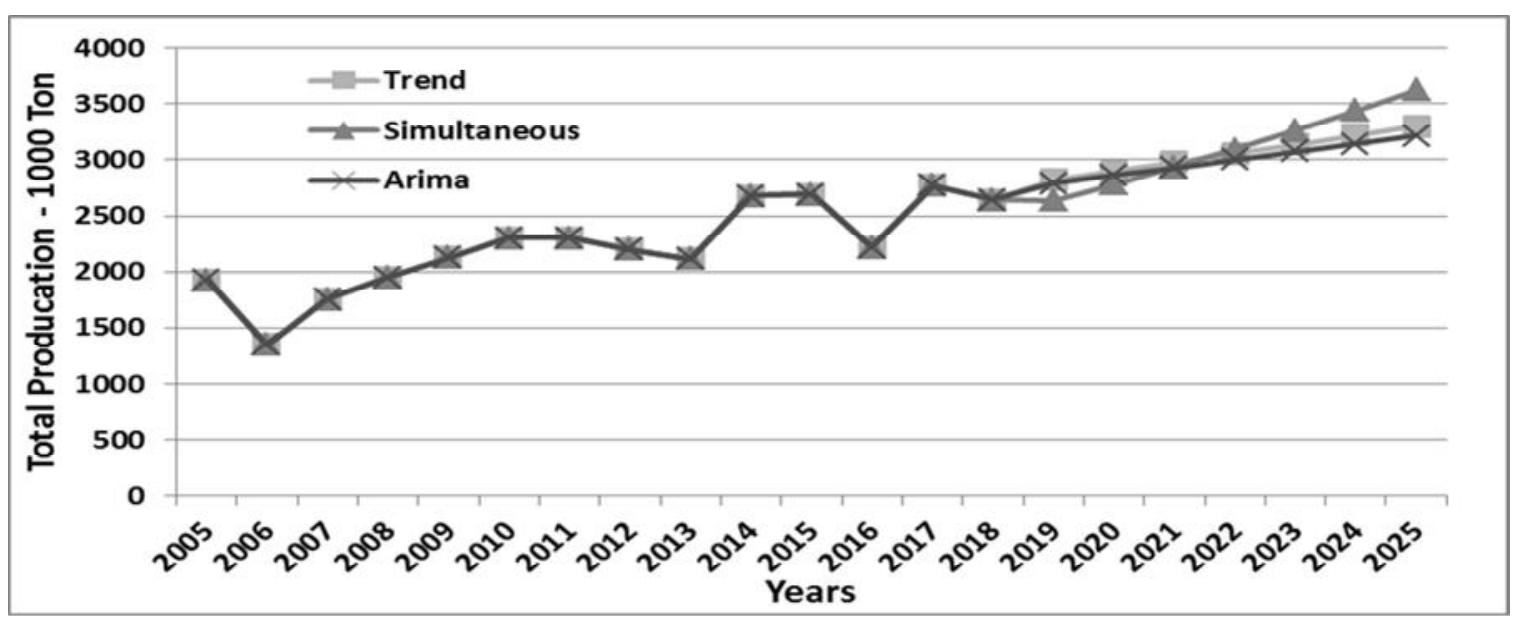

Fig. 6: A comparison between the prediction models of Egyptian GDP from Egyptian Onion (20202025).

Source: Tables (1 and 4) in the study.

\section{References}

Rania Abdullah El-Said, Economics of Major Export Vegetable Crops in the Arab Republic of Egypt, Ph.D. Thesis, Department of Agricultural Economics, Faculty of Agriculture, Ain Shams University, 2013.

Mohamed Zaki Gomaa, et al., Spending of Egyptian-European Participation on Agricultural Exports, Study of Potato and Orange Cases, Tenth Conference of Agricultural Economists, 25-26 September 2002.

Publications of the Central Agency for Public Mobilization and Statistics, Central Bank database.

Magdy El-Shorbagy, "Econometrics Theory and Practice," Dar Al-Masriya Al-Liban, First Edition, Arab Republic of Egypt, 1994

Madnani G.M.K, Introduction To Econometrics, Principles, and Applications, Oxford \&IBH Publishing co., 1986.

www.Faostat.Org.

www.Trademap.Org. 


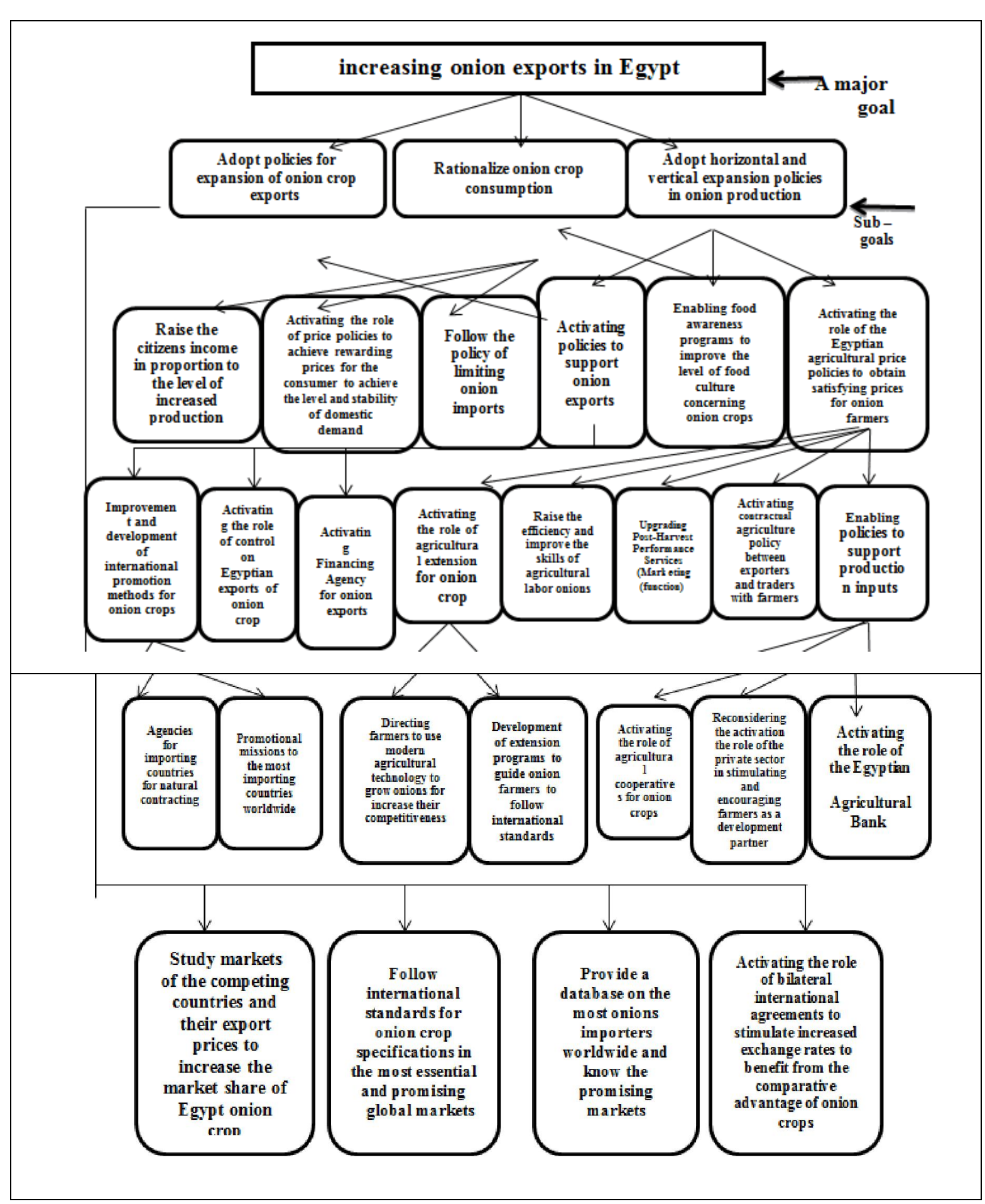




\section{Appendix}

Table 1: Simultaneous Model Variables in Logarithmic forms (2005-2018).

\begin{tabular}{ccccccccccc}
\hline Year & Y1 & Y2 & Y3 & X1 & X2 & X3 & X4 & X6 & X7 & X8 \\
\hline $\mathbf{2 0 0 5}$ & 3.0750 & 0.0414 & 0.9358 & -4.2681 & 7.1135 & 3.9357 & 6.2653 & 4.6347 & 5.3279 & 5.1358 \\
$\mathbf{2 0 0 6}$ & 2.9063 & -0.4194 & 0.5608 & -2.9140 & 7.1873 & 4.4272 & 6.0753 & 4.7536 & 5.5984 & 5.0752 \\
$\mathbf{2 0 0 7}$ & 2.8651 & -1.0190 & 0.8084 & -2.9662 & 7.3360 & 4.6728 & 6.1800 & 5.3083 & 5.4205 & 5.6802 \\
$\mathbf{2 0 0 8}$ & 3.0609 & -0.4200 & 0.8950 & -3.3743 & 7.5202 & 4.7983 & 6.7069 & 5.9789 & 5.4972 & 5.3660 \\
$\mathbf{2 0 0 9}$ & 3.3006 & -0.2524 & 0.9646 & -2.7749 & 7.6597 & 4.8481 & 6.7616 & 6.5751 & 5.6971 & 5.5683 \\
$\mathbf{2 0 1 0}$ & 3.1305 & 0.3466 & 1.0240 & -1.5736 & 7.7710 & 4.9001 & 5.5568 & 6.1159 & 5.9636 & 5.9269 \\
$\mathbf{2 0 1 1}$ & 3.1638 & 0.3513 & 1.0028 & -2.7496 & 7.8491 & 4.9530 & 6.9801 & 6.0845 & 6.0039 & 5.8081 \\
$\mathbf{2 0 1 2}$ & 3.1890 & -0.1000 & 0.9338 & -4.2155 & 7.9507 & 4.9551 & 7.7147 & 6.2005 & 6.1591 & 5.2627 \\
$\mathbf{2 0 1 3}$ & 2.8212 & 0.0139 & 0.8721 & -3.8787 & 8.0172 & 4.8275 & 8.0229 & 6.4216 & 6.2146 & 6.0088 \\
$\mathbf{2 0 1 4}$ & 3.2577 & 0.3102 & 1.0865 & -3.5700 & 8.0813 & 4.8986 & 8.3742 & 5.9814 & 6.2879 & 5.5373 \\
$\mathbf{2 0 1 5}$ & 3.3149 & 0.5453 & 1.0688 & -3.6159 & 8.1184 & 5.3683 & 8.5795 & 6.1247 & 6.3063 & 6.0137 \\
$\mathbf{2 0 1 6}$ & 3.0623 & 0.3752 & 0.8541 & -3.6618 & 8.1479 & 5.7500 & 7.0699 & 6.0707 & 6.4646 & 5.3375 \\
$\mathbf{2 0 1 7}$ & 3.2184 & 0.3366 & 1.0559 & -3.3765 & 8.0196 & 5.7857 & 7.2647 & 6.1225 & 6.3099 & 5.5645 \\
$\mathbf{2 0 1 8}$ & 3.2072 & -0.2188 & 0.9872 & -4.2686 & 7.9367 & 5.8201 & 7.5637 & 6.1675 & 6.3279 & 5.5175 \\
\hline
\end{tabular}

Source: Compiled and calculated from the Internet site Trade Map.

Table 2: Simultaneous Model Variables in Logarithmic forms (2005-2018).

\begin{tabular}{lllllllllllll}
\hline Years & X11 & X12 & X13 & X14 & X15 & X16 & x6t & X18 & X20 & X21t & Y1t & Y2t \\
\hline $\mathbf{2 0 0 5}$ & 5.976 & 1.754 & 9.446 & 10.647 & 8.401 & 10.661 & 4.625 & -1.917 & -1.434 & 3.928 & 2.855 & -0.061 \\
$\mathbf{2 0 0 6}$ & 6.105 & 1.746 & 9.558 & 10.734 & 8.667 & 10.712 & 4.635 & -1.513 & -0.926 & 3.936 & 3.075 & 0.041 \\
$\mathbf{2 0 0 7}$ & 6.337 & 1.729 & 9.668 & 10.802 & 8.931 & 10.766 & 4.754 & -1.602 & -0.917 & 4.427 & 2.906 & -0.419 \\
$\mathbf{2 0 0 8}$ & 6.263 & 1.692 & 9.823 & 10.872 & 9.168 & 10.785 & 5.308 & -1.637 & -1.133 & 4.673 & 2.865 & -1.019 \\
$\mathbf{2 0 0 9}$ & 6.014 & 1.713 & 9.792 & 10.891 & 9.131 & 10.690 & 5.979 & -1.589 & -1.400 & 4.798 & 3.061 & -0.420 \\
$\mathbf{2 0 1 0}$ & 6.277 & 1.727 & 9.839 & 10.895 & 9.208 & 10.628 & 6.575 & -1.543 & -1.508 & 4.848 & 3.301 & -0.252 \\
$\mathbf{2 0 1 1}$ & 6.347 & 1.780 & 9.947 & 10.906 & 9.312 & 10.615 & 6.116 & -1.514 & -1.480 & 4.900 & 3.130 & 0.347 \\
$\mathbf{2 0 1 2}$ & 6.163 & 1.801 & 10.087 & 10.877 & 9.509 & 10.629 & 6.084 & -1.480 & -1.460 & 4.953 & 3.164 & 0.351 \\
$\mathbf{2 0 1 3}$ & 6.326 & 1.927 & 10.144 & 10.877 & 9.629 & 10.651 & 6.201 & -1.487 & -1.491 & 4.955 & 3.189 & -0.100 \\
$\mathbf{2 0 1 4}$ & 6.277 & 1.957 & 10.148 & 10.859 & 9.608 & 10.691 & 6.422 & -1.412 & -1.552 & 4.828 & 2.821 & 0.014 \\
$\mathbf{2 0 1 5}$ & 6.035 & 2.040 & 10.074 & 10.816 & 9.389 & 10.689 & 5.981 & -1.297 & -1.555 & 4.899 & 3.258 & 0.310 \\
$\mathbf{2 0 1 6}$ & 6.198 & 2.305 & 9.981 & 10.756 & 9.201 & 10.655 & 6.125 & -1.293 & -1.551 & 5.368 & 3.315 & 0.545 \\
$\mathbf{2 0 1 7}$ & 6.028 & 2.878 & 9.903 & 10.756 & 9.146 & 10.611 & 6.071 & -1.265 & -1.257 & 5.750 & 3.062 & 0.375 \\
$\mathbf{2 0 1 8}$ & 6.394 & 2.877 & 9.978 & 10.845 & 9.249 & 10.629 & 6.122 & -1.234 & -1.507 & 5.786 & 3.218 & 0.337 \\
\hline
\end{tabular}

